\title{
E-ENTREPRENEURSHIP IN EU COUNTRIES: EVOLUTIONS AND CHALLENGES
}

\author{
Valentina-Diana RUSU(D) ${ }^{*}$, Angela ROMAN (iD ${ }^{2}$ \\ ${ }^{I}$ Institute of Interdisciplinary Research, Social Sciences and Humanities Research Department, \\ Alexandru Ioan Cuza University of Iasi, Lascar Catargi Street, No. 54, 700107, Iasi, Romania \\ ${ }^{2}$ Department of Finance, Money and Public Administration, Faculty of Economics and Business Administration, \\ Alexandru Ioan Cuza University of Iasi, Carol I Blvd, No. 22, 700505, Iasi, Romania
}

"E-mail: valentinadiana.ig@gmail.com

\begin{abstract}
Purpose - the purpose of this paper is to identify how entrepreneurs from European Union (EU) use informational and communicational technologies in their business activities. We also try to identify the benefits and the challenges arisen for the European entrepreneurs in using information technologies.

Research methodology - we analyze a sample of EU countries, by including them into two groups, according to the stage of their economic development. As methods, we use the logical-constructive method and also comparative methods. We also use the benchmarking method in order to estimate country indicators in the sample and compare them.

Findings - the results of our study emphasize that e-entrepreneurship in developed countries is more advanced compared to developing countries. There are also significant differences regarding the use of informational technologies between types of firms by their size.
\end{abstract}

Research limitations - are given by the availability of data.

Practical implications - we emphasize that in order to support the development of E-entrepreneurship in the EU, government policies should pay more attention to the development of information technology infrastructure.

Originality/Value - comes from grouping the EU countries into two groups, according to their stage of economic development. And, comparing the two groups as regards the use of informational and communication technologies.

Keywords: information technology, e-entrepreneurship, e-business, innovation, EU countries.

JEL Classification: L26, M15, M13.

Conference topic: Digitalization of Business Processes: Trends, Challenges, Solutions.

\section{Introduction}

The continuous and accelerated development of information technology in the last two decades has caused significant changes in business environment and has led to the emergence of new ways of undertaking entrepreneurial activities which, although they require an additional effort, knowledge, and work, help the start of new business and stimulate the development of existing ones. Regardless of their size, today's entrepreneurs have the possibility to use extensively the internet to do business and also reach new markets. Entrepreneurs need to adapt to the changing economic environment and to the rapid development of information technologies. E-entrepreneurship refers to entrepreneurial activities that are linked to digital data networks. In agreement with Matlay (2004), E-entrepreneurship describes the act of setting up new firms in the economy based on information technology and is understood as an entrepreneurial process used to create an e-business (Asghari \& Gedeon, 2010). E-business is a relatively new term that involves the use of information technologies by enterprises to conduct its core business.

Through this paper we aim to analyze how entrepreneurs from the European Union member states use e-business technologies, taking into account their dynamics over a period of eight years, between 2010 and 2018. Moreover, we have proposed making a comparative analysis between countries, grouping them according to their stage of economic development in transition countries or driven by innovation. In order to obtain more accurate results, we have also made a comparative analysis by the size class of enterprises (namely, small, medium and large).

Our paper contributes to completing the literature in the field by realizing an analysis of the European Union countries by grouping them into two groups, according to their stage of economic development. And, comparing the two groups as regards the use of informational and communication technologies. This kind of analysis, by groups of 
countries, have not been made in the literature. We also, bring something new to be considering an extensive period of eight years. Through our results, we emphasized the role played by the stage of economic development in how much is made use of e-entrepreneurship.

To achieve our objectives, we have structured this paper as follows: in the first part, we present a brief literature review of the main studies that analyze the relationship between entrepreneurship, innovation, and e-business. In the second part of the paper, we describe the data used and the methodology. In the third part, we present our main findings and we discuss them. Our study ends with conclusions.

\section{Literature review}

In the literature, we found a couple of studies analyzing the relationship between entrepreneurship, the use of informational and communication technologies, and innovation. For example, the study realized by Taylor and Murphy (2004) shows that the adoption of Information and communication technology and of e-business techniques is of vital importance for the growth of business in current economic conditions. IT technologies and e-business provide growth opportunities for businesses, which the decision makers from every country are willing to obtain. The authors also highlight the fact that in most countries decision-makers are very interested in engaging small and medium enterprises (SMEs) in the digital economy. However, the current levels of involvement of many small and medium-sized firms in the use of these new technologies are reduced and most often the techniques used are rudimentary. Most SMEs apply e-business by limiting themselves to using e-mail and creating websites. However, Manuel (2006) highlighted the fact that we are on the knowledge era, and the entrepreneurs need to be aware of this fact and to focus on introducing informational and communication technologies in their business strategies, and even change their business strategies according to the new environment because online business involves several challenges when these companies are in different virtual places and are having different customers, suppliers and rival companies.

In its study, Waesche (2003) has analyzed the role of telecommunications reform in affecting entrepreneurship, focusing especially on the case of Germany. Its results show that European telecommunication costs and restrictions posed several challenges to businesses.

Another study, realized by Amit and Zott (2001) emphasizes that e-business can create new value through the ways in which transactions are activated. The authors have proposed to identify common models of value creation when using e-business. Their results suggest that the emergence of virtual markets opens up new sources of innovation (e.g. business model innovation) that may require a parallel shift in strategic thinking towards more integrative, dynamic, adaptive and entrepreneurial strategies.

Other studies in the field (Carayannis \& Zedwitz, 2005; Zhao, 2005) investigated the relationship between entrepreneurship and innovation and their role in organizational development in general and in the dot-com industry in particular. Their results have shown the important role of e-entrepreneurship in delivering innovative entrepreneurial activities. Zhao (2005) argues that entrepreneurship and innovation are complementary, and a combination of them is of major importance for the long-term sustainability of e-commerce and e-business. Jelonek (2015) emphasize also the relationship between e-entrepreneurship and innovation and shows that Internet technology brings numerous benefits for entrepreneurs, such as lower operating costs and the possibility to operate on a scale that is larger than before.

Asongu and Nwachukwu (2018) have examined how ICT influences openness to improve conditions of doing business in sub-Saharan Africa for the period 2000-2012. Their results show substantial evidence that ICT complements openness to improve conditions for entrepreneurship, but the effects are contingent on the dynamics of openness, ICT, and entrepreneurship.

Other studies (Bandera, Collins, \& Passerini, 2018; Cujia Berrio, Redondo, \& Hernández, 2018; Barnett, Hu, \& Wang, 2019) have found that the use of ICT has positive effects on entrepreneurs, is stimulating them and is moderating the relationship between entrepreneurial attitudes and risk. Moreover, the increase in information available due to new technologies positively affects aggregate entrepreneurship in national economies (Hanoteau \& Rosa, 2019). The Global Entrepreneurship Monitor also suggested that information technologies explain a large portion of the increase in entrepreneurship (GEM, 2018)

Finkle, Krovi, Kahai, Dunning, and Vijayaraman (2000) show that entrepreneurs and small businesses face many opportunities and can take advantage of the development of the Internet, but they must create a kind of sustainable competitive advantage. The authors also indicate that e-commerce is growing at such a rapid pace that in the near future there will be enough opportunities for entrepreneurs and small businesses. However, although the market shows that there is always room for new innovative ideas and e-business products, the mentioned authors believe that low barriers to entry and increased competition will result in lower prices and profits, which will make businesses or more and more difficult to survive.

Guillén and Suárez (2001) have shown that the Internet has not developed throughout the world in a uniform way. The percentage of the population which uses the internet in a regular way varies from over $50 \%$ in the Scandinavian region to less than 1\% in many underdeveloped African, Central American, and South Asian countries. The differences in Internet development across countries are accounted for by per capita income, and by the existing infrastructure and competition in the telecommunications sector (Hargittai, 1999; Oxley \& Yeung, 2001). The results obtained by Guillén 
and Suárez (2001) showed the existence of a significant relationship between entrepreneurial activities, investments, and internet development. They also emphasized that the internet development, measured in terms of the numbers of users and hosts, is higher in countries with conditions that favor entrepreneurship and investment, and with a democratic political system.

Several studies (Powell \& Micallef, 1997; Kohli \& Devaraj, 2003; Melville, Kraemer, \& Gurbaxani, 2004; Pavlou \& Ei Sawy, 2006; Chae, Koh, \& Prybutok, 2014) have analyzed the strategic significance of ICTs for sustaining the competitive strategies and improving firm performance. Many firms from the European Union adopt information and communication technologies for ensuring their survival and growth, but also for being competitive and enhancing innovation abilities (Nguyen, 2009). Adopting new information and communication technologies is also a way to enhance the way in which people capture and distribute information, lower production and labor costs, add value to products and services and increase the company's competitive advantage, applying ICTs in business determines the production and administration processes to be technology-intensive (Nguyen, 2009).

The study of Amankwah-Amoah, Osabutey, and Egbetokun (2018) highlights the importance of new technologies to the innovative capacities of the prevalent informal sector in Africa. Their result shows that the adoption of new technologies has been favorable for the SMEs in Africa because it helped them to align with have technological innovations, and offered means of creating new opportunities as well as expanding their businesses. The authors also point out the need for the involvement of the state institutions in helping businesses adopt information and communication technologies.

The analysis of the literature on the use of information technology by firms of different sizes shows that a growing number of studies focus on investigating the factors that influence the adoption and use of e-business technologies by entrepreneurs and SMEs. Thus, based on a sample of SMEs in Turkey (Kaynak, Tatoglu, \& Kula, 2005) examine the factors that encourage firms to make e-commerce via the Internet. Research findings show that the adoption of e-commerce by the investigated SMEs is significantly influenced by the benefits of using it. The authors also find that the limitations associated with the use of e-commerce would not have a significant effect on its adoption. However, the study suggests that a lack of legal regulations and security issues are among the most important limitations of adopting e-commerce by SMEs. Daniel and Grimshaw (2002) compare the reasons why small and large businesses in the UK use e-commerce and the benefits of using it. The results of the study indicate that a larger percentage of small businesses are using e-commerce in order to respond to competitors by providing improved customer service and improving supplier relationships. By comparison, large firms have a greater interest in adopting e-commerce for reasons of operational efficiency. Thus, the authors point out that small businesses regard e-commerce as an opportunity to improve their performance while for large firms, e-commerce is viewed more defensively, especially as an opportunity to increase operational efficiency. Another study (Stansfield \& Grant, 2003) discusses the main problems and obstacles which appear in the way of adopting and using the Internet and e-commerce by SMEs, especially by micro and small businesses. Research findings indicate that lack of knowledge, skills, and lack of counseling and support would be important factors that would influence firms not to adopt the Internet and electronic commerce. The authors also point out that most of the small businesses investigated are in the early stages of Internet adoption, and few companies show the inclination towards its full integration. MacGregor and Kartiwi (2010) investigate the barriers to the adoption and use of electronic commerce by SMEs in developed countries as compared to those in developing countries. Based on the questionnaire survey, the study indicates differences in the prioritization of barriers to e-commerce between the two locations. Thus, SMEs in a developed economy (Sweden) are more concerned with technical issues while firms in a developing economy (Indonesia) are more concerned with organizational barriers. Another author (Ifinedo, 2011) analyzes the factors that influence the acceptance of the Internet and e-business technologies by Canadian SMEs. The authors find that perceived benefits, as support offered by the management, and external pressure (exerted by competitors, suppliers, and customers) are the most important determinants of accepting new technologies by Canadian SMEs. Using data for a sample of SMEs in Iran (Solaymani, Sohaili, \& Yazdinejad, 2012) analyze the factors that influence the adoption and use of e-commerce by these companies. The results of the study show that the tendency of SMEs to adopt and use e-commerce is positively linked to minimum annual internet costs. The authors also find that financial issues and uncertainty in the e-commerce market are the most important barriers to adopting and using e-commerce by sampled SMEs. In the case of a more recent study (Chivasa \& Hurasha, 2016), authors find that internet cost, ICT infrastructure, management attitude, and knowledge have a direct impact on adopting and using e-commerce. In addition, the authors point out that the majority of SMEs surveyed prefer the traditional way to do business because they fear the risk of financial losses associated with electronic commerce.

The review of literature that regards the way entrepreneurs from different countries use information and communication technologies in their activities indicates a rather small number of research focused on European countries. Therefore, our research contributes to the literature by providing evidence of the differences that exist between EU countries in terms of the adoption and use of information and communication technology by entrepreneurs.

\section{Data and methodology}

The main purpose of our empirical analysis is to identify how entrepreneurs include information technologies in their business activities in the European Union member countries. We intend to identify if there are differences between 
countries in the use of information technologies according to their stage of economic development. More precisely, we want to see if higher levels of economic development determine the use in a higher proportion of informational technologies by entrepreneurs. We also aim at identifying if there might be a relationship between the use of e-entrepreneurship and the increase in the number of new and innovative entrepreneurs.

For achieving the main objective, we considered a sample of 28 countries members of the European Union: Austria, Belgium, Bulgaria, Croatia, Cyprus, Czech Republic, Denmark, Estonia, Finland, France, Germany, Greece, Hungary, Ireland, Italy, Latvia, Lithuania, Luxembourg, Malta, the Netherlands, Poland, Portugal, Romania, Slovak Republic, Slovenia, Spain, Sweden and the United Kingdom. We have collected the data for the period 2010-2018. The data were obtained from the Eurostat database (European Commission, 2018) and The World Bank DataBank (World Bank, 2018).

To emphasize how entrepreneurs from countries with different stages of economic development use information technologies in their business activities, we have grouped the considered countries in different groups according to their stage of economic development, starting from the classification made by Schwab and Sala-i-Martin (2017), considering the level of GDP per capita as criterion: efficiency-driven economies, in transition between efficiency and innovation, and innovation-driven economies.

According to the Global Competitiveness Report (Schwab \& Sala-i-Martin, 2016), the economies from the efficiency-driven stage of development must begin to develop more efficient production processes and increase product quality because wages have risen and they cannot increase prices. At this point, competitiveness is increasingly driven by higher education and training (5th pillar), efficient goods markets (6th pillar), well-functioning labor markets ( 7 th pillar), developed financial markets (8th pillar), the ability to harness the benefits of existing technologies (9th pillar), and a large domestic or foreign market (10th pillar). Moving forward, when the countries shift to the innovation-driven stage, wages will have risen by so much that they are able to sustain those higher wages and the associated standard of living only if their businesses are able to compete using the most sophisticated production processes (11th pillar) and by innovating new ones (12th pillar).

The classification of the EU-28 countries is presented in Table 1 below. Because, Bulgaria is the only country from our sample included in the efficiency-driven stage, and we will not obtain accurate results when making a comparison with only one country, for further analysis we included Bulgaria also in the transition stage. Therefore, for our empirical investigation, we analyze two groups of European Union member countries: with economies in transition and innovation-driven economies.

As regards the relationship between the use of informational and communication technologies in entrepreneurial activities and innovation the literature has shown that ICTs can be a tool in encouraging innovation (Johannessen, 1994). Karadal and Saygin (2011) analyzed the effects of information technology on innovation. Their results highlight that businesses sustain that information technology has a significant effect on innovation, the firms use the information technologies in an active way and with their help are trying to create new product ideas and make their productions convenient for their customers' needs.

Table 1. The classification of EU-28 countries according to their stage of development (source: processed by the author after Schwab and Sala-i-Martin, 2017 and Schwab, 2018)

\begin{tabular}{|c|l|l|l|l|}
\hline & \multicolumn{4}{|c|}{ Stage of economic development } \\
\hline & $\begin{array}{c}\text { Stage 2: } \\
\text { Efficiency-driven }\end{array}$ & $\begin{array}{c}\text { The transition from stage } \\
\text { 2 to stage 3 }\end{array}$ & \multicolumn{2}{c|}{$\begin{array}{c}\text { Stage 3: } \\
\text { Innovation-driven }\end{array}$} \\
\hline $\begin{array}{c}\text { GDP per capita } \\
\text { (in USD) }\end{array}$ & $3.000-8.999$ & $9.000-17.000$ & \multicolumn{2}{c|}{$>17.000$} \\
\hline & Bulgaria (8.064) & Croatia (13.138,3) & Austria (47.290) & Ireland (70.638,3) \\
\hline & & Hungary (15.531,2) & Belgium (43.582) & Italy (31.984) \\
\hline & & Latvia (15.547,2) & Cyprus (24.976,2) & $\begin{array}{l}\text { Luxembourg } \\
(105.803,1)\end{array}$ \\
\hline & & Lithuania (16.730,2) & Czech Republic (20.152,4) & Netherlands $(48.345,7)$ \\
\hline & & Poland (13.822,6) & Denmark (56.444,1) & Malta (27.250,4) \\
\hline & Romania (10.757) & Estonia (19.840,1) & Portugal (21.161,3) \\
\hline & & Slovak Republic & Finland (46.016,7) & Slovenia (23.654,4) \\
\hline & & & France (39.869,1) & Spain (28.358,8) \\
\hline & & & Germany (44.549,7) & Sweden (53.217,6) \\
\hline & & & Greece (18.637,3) & $\begin{array}{l}\text { United Kingdom } \\
(39.734,6)\end{array}$ \\
\hline
\end{tabular}

Note: GDP per capita, in USD, values are in parenthesis. 
Awazu et al. (2009) showed that ICTs enable the entire innovation process, from idea generation and development to experimenting and testing, and, finally, to the commercialization of ideas, and that the use of information technologies has already brought many important changes to innovation management.

In their study, Urbinati, Chiaroni, Chiesa, and Frattini (2018) underlined that the informational technologies have become a key enabler of innovation because a high number of firms are using digital technologies to manage their innovation processes. Also, they point out that digital technologies can be used and implemented to manage open innovation processes through easier access and sharing the knowledge created and transferred.

Starting from those stated above we formulate the hypothesis that we intend to test in this study:

Hypothesis 1: the entrepreneurs from more developed countries use in a higher proportion of informational and communication technologies compared to those from developing countries.

Hypothesis 2: the countries where e-entrepreneurship is more present have more innovative entrepreneurs.

As methods of analysis, we use the logical-constructive method and also comparative methods because we put face to face the theoretical notions with empirical data. We also use the benchmarking method in order to estimate country indicators in the sample and compare them. Moreover, the graphical method allows us to realize a visual analysis and helps with further analysis.

\section{Results and discussions}

The results of our empirical analysis highlight important differences between the European Union member countries as regards the adoption and utilization of the informational and communicational technologies at the enterprise level. For analyzing the evolution of the considered indicators in the period of eight years, and also for comparing the indicators obtained for the two groups of countries, we consider the values in a relative form. First of all, because the data from Eurostat were available in the percentage of enterprises and, second of all, for realizing a comparison we consider to be more useful to use percentage values. Taking into account that we analyze countries with different levels of development, a certain number of enterprises might be significant for a less developed economy while it can be insignificant for a more developed economy. As presented in Figure 1, in 2018, 97\% of the businesses from European Union countries had access to the internet. The access to the internet has increased with three percentage points in 2018 compared to 2010 when only $94 \%$ of the business had internet access. We consider as criteria of measuring a significant change in the value of $1 \%$ because this percentage sometimes can express tens or hundreds of thousands of enterprises.

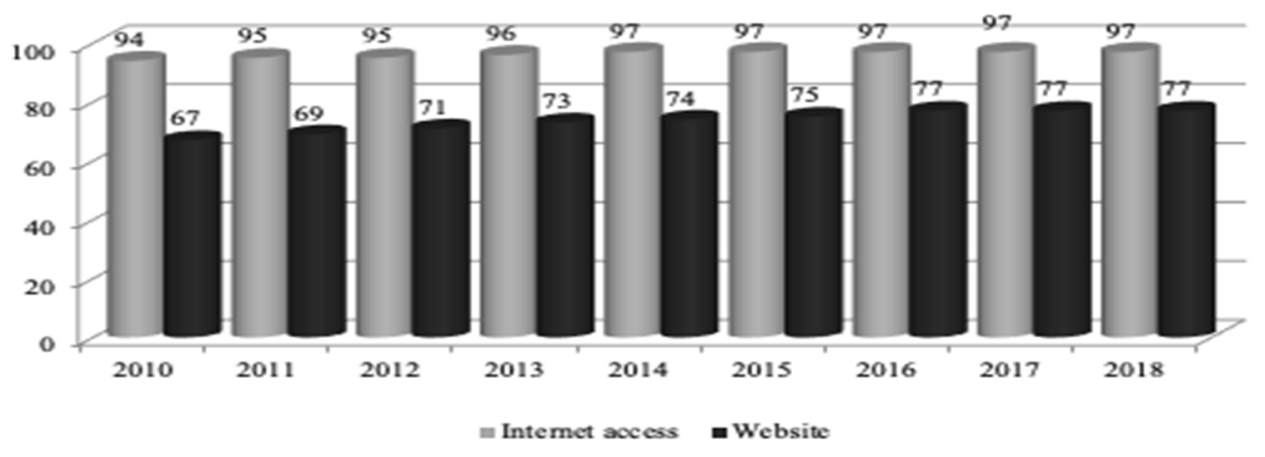

Figure 1. The use of informational technologies in enterprises from the European Union, evolution between 2010 and 2018 (as \% of enterprises) (source: processed by the authors after ec.europa.eu/eurostat)

Also, more and more entrepreneurs consider that it is very important for their business to be visible on the internet. So that the websites enterprises offer higher functionality, such as the possibility of online ordering, product and information catalogs, order tracking, product customization, social networking. Therefore, the empirical evidence shows that in 2018, around $77 \%$ of the firms from the European Union declared having a website. The percent of enterprises with a website registered a significant increase in the last year, accordingly compared to 2010 was registered an increase of ten percentage points. Based on the data from Table 2 we realized a comparative analysis of the European Union member countries as regards the access to the internet and the existence of a website between the reference year 2010 and 2018.

The share of businesses that have a website was, in 2018, above the EU average for 15 of the 28 European Union member countries. Therefore, for fifteen EU countries, $77 \%$ or more businesses reported having a website. The situation has improved, in 2018 compared to the reference year 2010, when only $67 \%$ of the European Union enterprises reported they had their own website. In 2018, at the bottom of the ranking were: Romania (only 44\% of the enterprises were having a website), Bulgaria (51\% of businesses), Latvia and Portugalia (with $63 \%$ of businesses). 
Table 2. E-entrepreneurship presence in European Union member countries, 2010 and 2018 (source: processed by the authors after ec.europa.eu/eurostat)

\begin{tabular}{|c|c|c|c|c|c|c|c|c|c|}
\hline \multirow{2}{*}{ Country } & \multicolumn{2}{|c|}{ Website } & \multicolumn{2}{|c|}{ Internet access } & \multirow{2}{*}{ Country } & \multicolumn{2}{|c|}{ Website } & \multicolumn{2}{|c|}{ Internet access } \\
\hline & 2010 & 2018 & 2010 & 2018 & & 2010 & 2018 & 2010 & 2018 \\
\hline EU & 67 & 77 & 94 & 97 & LV & 48 & 63 & 91 & 100 \\
\hline AT & 80 & 88 & 97 & 100 & $\mathrm{LT}$ & 65 & 78 & 96 & 100 \\
\hline $\mathrm{BE}$ & 78 & 84 & 97 & 99 & LU & 70 & 83 & 96 & 100 \\
\hline BG & 37 & 51 & 85 & 95 & $\mathrm{HU}$ & 57 & 66 & 90 & 91 \\
\hline $\mathrm{CZ}$ & 67 & 77 & 94 & 97 & MT & 66 & 82 & 94 & 96 \\
\hline $\mathrm{CY}$ & 52 & 71 & 88 & 96 & NL & 81 & 94 & 98 & 100 \\
\hline DK & 88 & 96 & 97 & 100 & PL & 65 & 67 & 96 & 96 \\
\hline $\mathrm{DE}$ & 81 & 87 & 97 & 99 & PT & 52 & 63 & 94 & 98 \\
\hline EE & 70 & 78 & 96 & 99 & RO & 35 & 44 & 79 & 86 \\
\hline IE & 68 & 79 & 92 & 97 & SI & 73 & 84 & 97 & 99 \\
\hline GR & 58 & 65 & 90 & 86 & SK & 74 & 76 & 98 & 96 \\
\hline ES & 62 & 76 & 97 & 98 & FI & 87 & 96 & 100 & 100 \\
\hline FR & 58 & 69 & 97 & 99 & SE & 89 & 92 & 96 & 99 \\
\hline HR & 61 & 73 & 95 & 97 & UK & 76 & 82 & 91 & 94 \\
\hline IT & 61 & 71 & 94 & 97 & & & & & \\
\hline
\end{tabular}

Note: expressed as percentage of enterprises.

At the other end of the ranking, with best results regarding the existence of a website for the enterprises we find: Finland and Denmark (96\%), Netherlands (94\%) and Sweden (92\%). These results confirm our firsts hypothesis that the entrepreneurs from more developed countries use in a higher proportion e-business technologies compared to those from developing countries, because at the top of the ranking regarding the businesses that have a website we find mainly the Nordic countries and at the end there are Central and Eastern European countries, which have emerging economies and are former socialist countries.

The biggest improvements in the percentage of enterprises having a website, in 2018 compared to 2010, were recorded in Cyprus (an increase of 19 percentage points), Malta (with an increase of 16 percentage points) and Latvia (15 percentage points). All the considered countries had registered an increase in the percentage of enterprises that have a website.

The share of businesses with Internet access was, in 2018, higher in almost all the countries considered in the analysis. In 19 of the 28 EU countries, $97 \%$ or more businesses reported having access to the internet. The bottom of the ranking is occupied by Romania and Greece (where only $86 \%$ of the enterprises reported having access to the internet in 2018), and Hungary (with $91 \%$ of the enterprises with access to internet). The situation is better compared to 2010 when only $94 \%$ of the enterprises from the European Union had access to the internet. Moreover, in 2010, were eight countries were situated under the average for the EU. In 2010, Romania was still at the bottom of the ranking, with only $79 \%$ of the enterprises that had access to the internet. Other countries with values under $90 \%$, in 2010, were: Bulgaria, Cyprus, Greece, and Hungary.

As regards the top of the ranking, in 2018, seven countries reported that $100 \%$ of their enterprises had access to the internet (Austria, Denmark, Latvia, Lithuania, Luxembourg, Netherlands, and Finland), compared to 2010, when only entrepreneurs from Finland had $100 \%$ access to the internet.

The biggest improvements of Internet access for businesses, in 2018 compared to 2010, were recorded in Bulgaria (10 percentage points), Latvia ( 9 percentage points), Cyprus ( 8 percentage points), and Romania ( 7 percentage points). From the countries considered in the analysis were also two countries that registered a reduction of Internet access for enterprises: Greece (a reduction of 4 percentage points) and Slovakia ( -2 percentage points), and Poland with a stagnation of the percentage of enterprises having internet access.

When analysing the evolution of the share of enterprises that have a website by groups of countries according to the stage of economic development (innovation-driven economies and transition economies), we observe that in the transition countries only 55\% of the businesses had in 2010 a website, while in the innovation-driven ones $71 \%$ of the businesses had a website (see Figure 2).

The results for the transition economies were situated below the EU average (of 67\%) while for the innovationdriven economies were situated above. Although the evolution in 2018 was positive and somewhat significant ( 9 and respectively, 10 percentage points compared to 2010), the economies in transition still record values below the EU average (of 77\%) for the enterprises holding a website, while the innovative countries are situated above the average. 


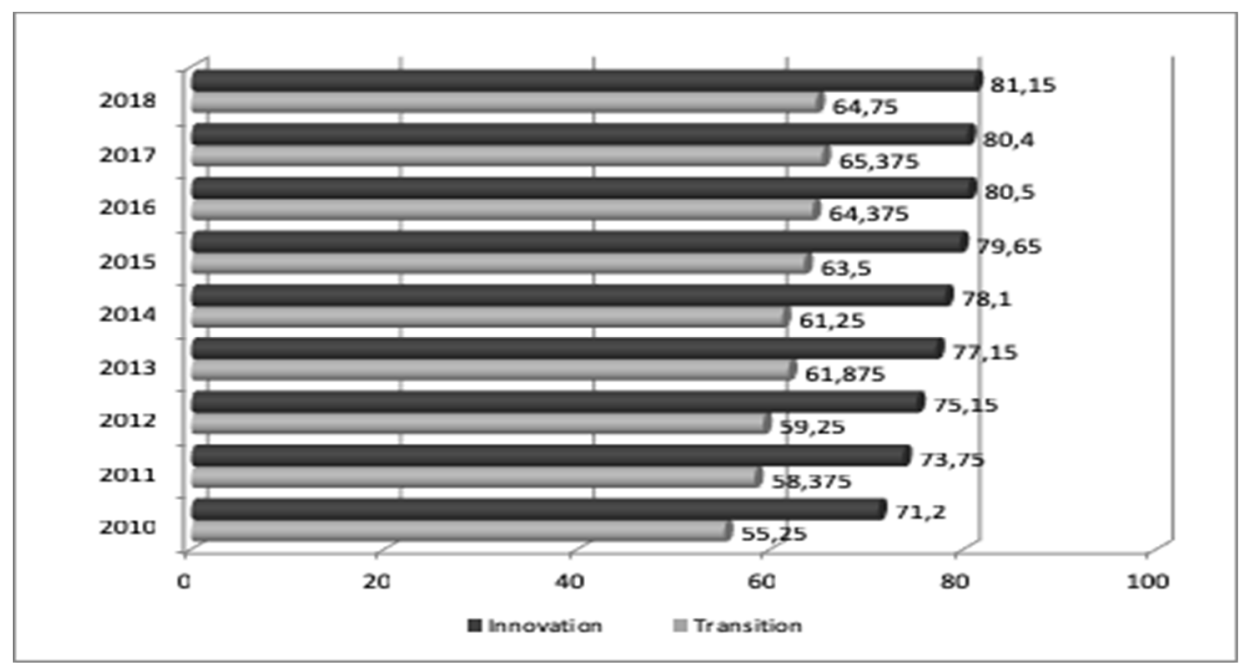

Figure 2. Percentage of EU enterprises having a website, by groups of countries (source: processed by the authors after ec.europa.eu/eurostat)

Figure 3 is summarizing the dynamics of internet access for enterprises by grouping the countries according to their stage of economic development. The results obtained, confirm once again hypothesis one, and show that the innovation-driven economies have more enterprises with access to the internet compared to the transition economies. The values obtained are around the mean for EU-28, in minus (with 3 percentage points in 2010, and with 2 percentage points in 2018) for the transition countries, and in addition (with one percentage point) for the innovation-driven countries for the entire period. Moreover, evolution over the years is positive for both groups of countries.

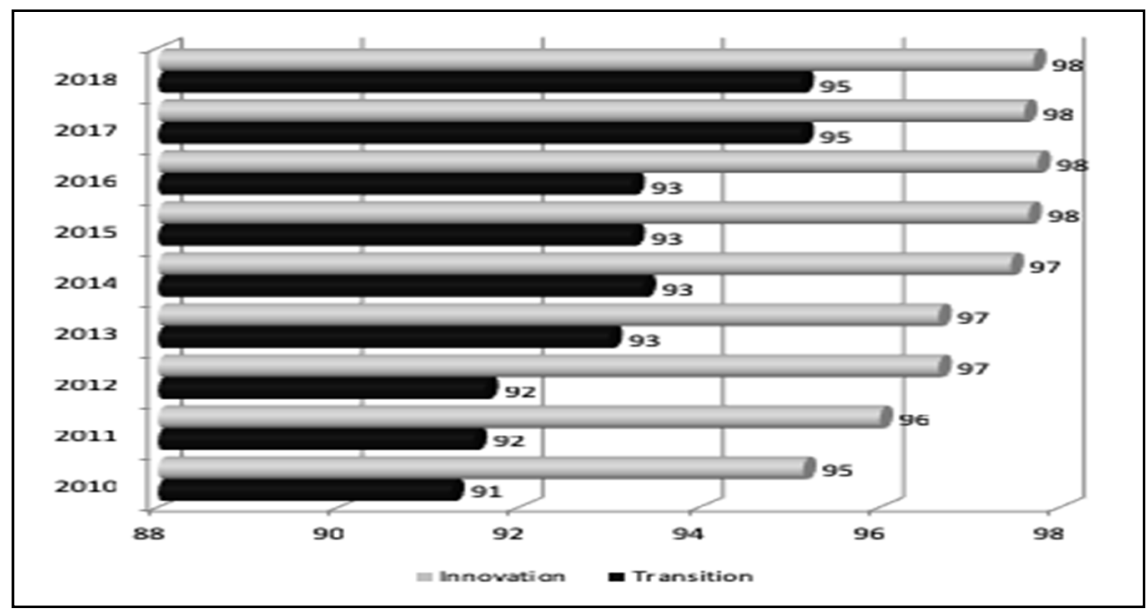

Figure 3. Percentage of EU enterprises with internet access, by groups of countries (source: processed by the authors after ec.europa.eu/eurostat)

Small and medium enterprises (SMEs) are considered the engine of economic and social development of a country, appreciation resulting from the fact that they generate a great part of a country's gross domestic product and are an important source of job creation. The major importance of these enterprises to the national economy results from the fact that, through their dynamism, they are considered an engine of innovation and growth. The role of SMEs in the national economy can be highlighted based on their overwhelming share in the total number of enterprises (Roman $\&$ Rusu, 2011). This is the reason why we have considered important to also analyze how the enterprises use informational technologies according to their size. When we analyze the use of international technologies by the European Union enterprises according to their size class (see Figure 4) we notice that as the size of the enterprise grows also grows the percentage of businesses that own a website or have access to the internet. Small enterprises (presented by Eurostat as the enterprises that have between 10 and 49 persons employed) reported, in 2018, values for the use of informational technologies below the European Union average. Medium sized enterprises, that have between 50 and 249 persons employed, and large enterprises, with more than 250 persons employed reported values above the average regarding the use of informational technologies. 


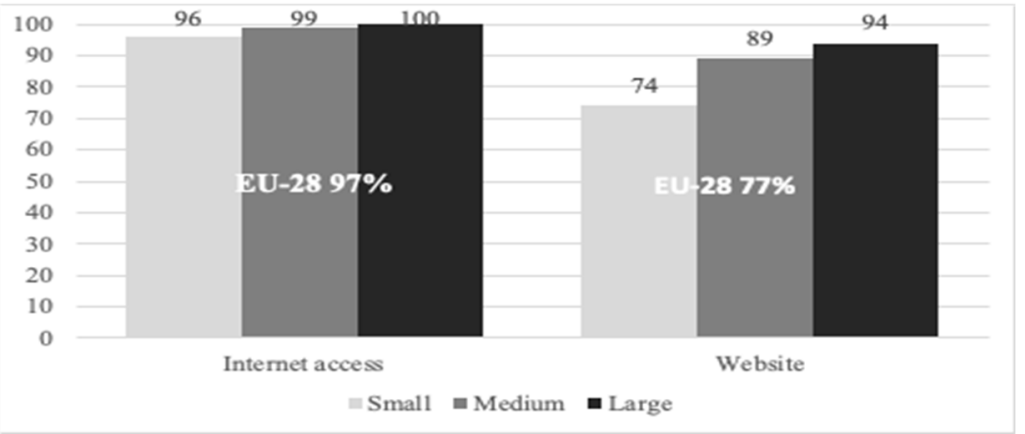

Figure 4. Percentage of EU enterprises adopting informational technologies by size class, 2018 (source: processed by the authors after ec.europa.eu/eurostat)

The situation becomes different when we continue our analysis regarding internet access by the size of the enterprises but we differentiate the countries by their stage of economic development (see Figure 5). For large enterprises, internet access has not changed from 2010 to 2018. Also, the percentage of enterprises that have access to the internet in similar for large enterprises from transition and innovation economies. For the enterprises of other sizes, we have found important differences. Therefore, the share of small enterprises that have access to the internet is smaller in the case of emerging economies compared to the innovative ones. However, it is worth noting that the percentage of small enterprises in transition countries that have access to the Internet has increased significantly in 2018 compared to 2010 (with four percentage points). An improvement is also registered for access to the internet in small enterprises from more developed countries. This fact emphasizes the significant role that information technologies are starting to play in the business activities of SMEs.

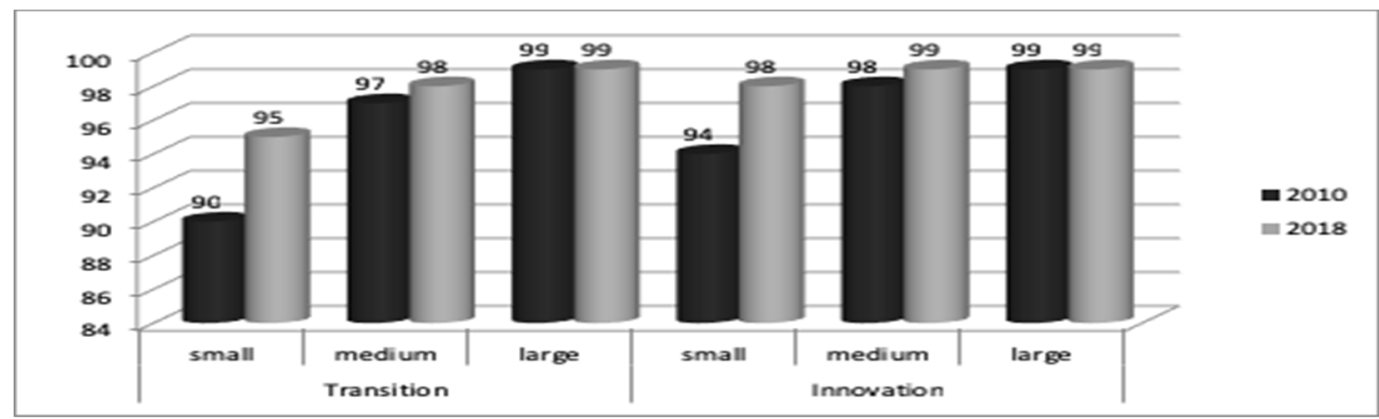

Figure 5. Enterprises with internet access by size class, and by groups of countries, 2018 compared to 2010 ( $\%$ of enterprises) (source: processed by the authors after ec.europa.eu/eurostat)

A particular element is represented by the fact that, even though in 2018 there is an increase in the share of small enterprises that have internet access compared to 2010 for both groups of countries, only in innovation-driven countries the value has reached the average registered for the EU $28(97 \%)$. Once again it is confirmed the fact that the smaller the enterprise, the more difficult it is for it to adapt to the changes that occur in the external environment, in our case to the e-entrepreneurship practices. The situation for medium enterprises is better, because the percentage of medium enterprises that had access to the internet in 2018 is similar with the percentage of large enterprises, in more developed countries, and almost similar in transition economies.

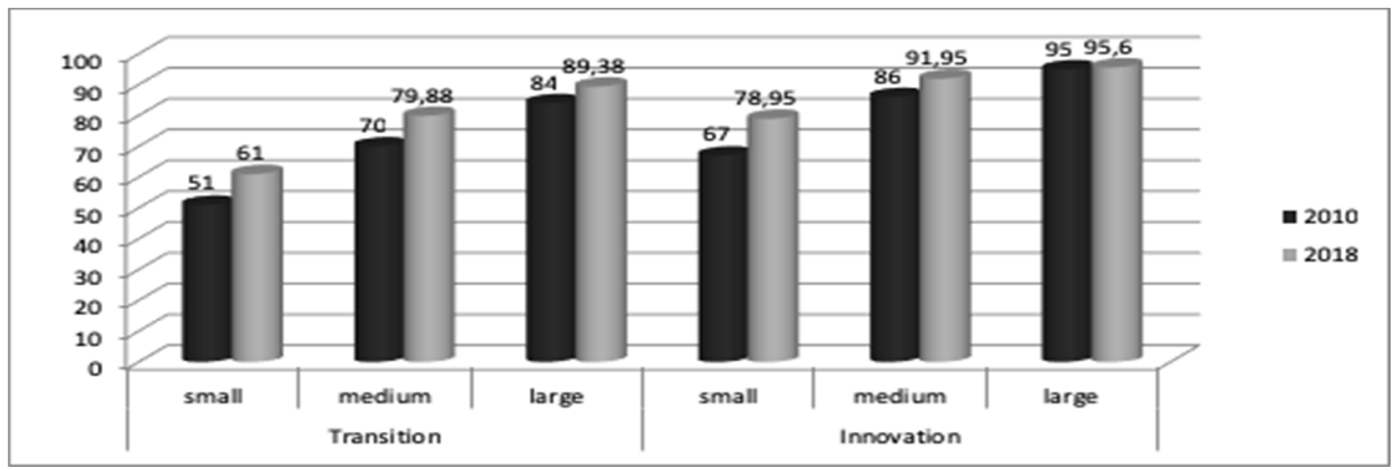

Figure 6. Enterprises having a website by size class, and by groups of countries, 2018 compared to 2010 ( $\%$ of enterprises) (source: processed by the authors after ec.europa.eu/eurostat) 
Focusing on the share of enterprises having a website we found that both for transition and for innovation-driven countries the percentage of enterprises having a website is lower for the small sized ones (see Figure 6). The share of enterprises that have a website is smaller in the transition countries for all the categories. While large enterprises had registered values above the EU 28 average as regards the existence of a website both in the reference year and in 2018 . As the size of the enterprise decreases, the percentage decreases, reaching values below the EU average for small businesses.

The adoption of the information and communication technologies can be represented graphically by an S-shape curve of cumulated adopters (see Figure 7). Cumulative adoption rates (measured by the percentage of enterprises) progress slowly at the beginning, and then start to accelerate and eventually slow down and stabilize as they approach the saturation point. In this theoretical adoption model represented by the S-curve, we did not consider the temporal dimension; this fact shows that the analyzed countries can evolve at different speeds in time.

As shown in Figure 7, the cumulative rates of businesses that have a website have a rapid acceleration, then deceleration and ultimately saturation. The point of saturation is situated around $90 \%$ in the majority of the countries considered in the analysis. Although almost all countries are in a progressive phase of having a website, the cumulative adoption rates are rising at a slower pace when approaching a theoretical saturation point.

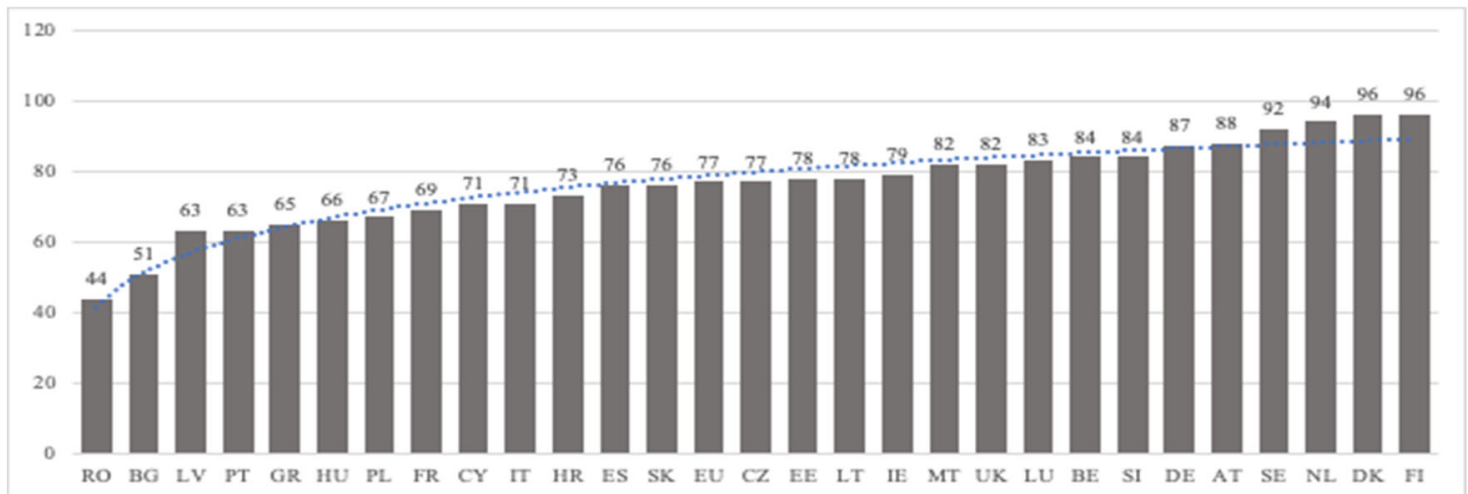

Figure 7. Enterprises holding a website, 2018 (\% of enterprises) (source: processed by the authors after ec.europa.eu/eurostat)

As regards the effects of the use of informational and communicational technologies, several studies (Dutta \& Evrard, 1999; Daniel \& Grimshaw, 2002; Levenburg, Schwarz, \& Motwani, 2005; Ajmal, Yasin, \& Norman, 2017) emphasized that by adopting and increasing the use of information technologies, especially the Internet, the firms have the possibility to improve their image, communication relationships, access to information, transactions with customers and suppliers, which would help to increase sales and profit. Szczepański (2015) emphasizes that Information and communication technologies allow cost savings for companies and governments, increasing access to new markets and facilitating the creation of new businesses. The author points out that small and medium businesses that are on the web and who use online marketing are growing four times faster than firms that are not present on the internet, and businesses with a digital dimension record higher revenue and greater profitability compared to non-digital businesses. Kaynak et al. (2005) emphasize that developing an internet business has significant benefits, including establishing direct relationships with customers, suppliers, and distributors; it facilitates information transfer; allows companies to create new products and services, but also to commercialize products around the world without physically contacting customers.

When focusing the attention on the relation between e-entrepreneurship and innovation the literature shows that ICT usage is an enabler of innovation in business activities. Especially in developing countries, the informational technologies are seen as instruments sustaining the development of entrepreneurs (Sin Tan, Choy Chong, Lin, \& Cyril Eze, 2009) and significant determinants of the successful implementation of radical new business strategies (Markides \& Anderson, 2006). Besides the technological progress determined by the use of ICTs, it has determined the existence of a variety of innovation potentials. For example, the use of ICT enables firms to restructure their organizations (flattening of hierarchies and delegating responsibilities), to re-engineer business processes (like introducing just-in-time management or engaging in E-commerce) and to develop completely new products (e.g. software or online services). These complementary innovations often involve high additional expenses, such as for reorganizations and for training workers (Hempell, van Leeuwen, \& van der Wiel, 2004). Realizing an extensive review of the literature, Eranga, Kennedy, and Dushyanta (2015) highlight that ICT usage stimulates all four main types of innovation, namely product, process, market and organizational. Moreover, the results of the study realized by Cuevas-Vargas, Estrada, and LariosGómez (2016) showed that there exists enough empirical evidence regarding the fact that ICTs are a facilitator of innovation, influencing it significantly and positively. Also, they showed that innovation and the use of ICTs substantially impact the performance of the businesses studied. After a panel regression analysis, the results obtained by Zoroja (2016) confirmed the impact of ICTs as a supporting factor for innovation activities. 
Other studies (Spiezia, 2011) also point out the significant relationship between the use of informational and communicational technologies in business activities and their inclination to innovate but also suggest that ICTs enable firms to adopt innovation but they do not increase their "inventive" capabilities. The results of the mentioned author showed that are significant differences in the effects of e-entrepreneurship on the implementation of innovation in business activity according to the sector of activity. Thus, for the manufacturing sector, the firms from Italy, Netherlands, and Switzerland that have a web site were 35\%, 12\% and 7\% more likely to innovate in a process than firms with no web facilities. For the services sector, a significant effect of ICT on innovation was found in Spain (37\%), Italy $(27 \%)$ and Norway $(16 \%)$.

But, all the positive and significant effects of e-entrepreneurship on innovation might be reduced because, as shown by van Deursen and van Dijk (2014) in developing countries appear gaps in ICT knowledge among workers. So, there may be a problem related to the fact that employees and even managers need to learn how to use ICTs and no longer give the importance of finding innovative ideas.

\section{Conclusions}

Entrepreneurship is seen as a determining factor for the economic development of a country, but it is also important for creating new jobs and for innovation. The constant development of electronic information and communication technologies is helping entrepreneurs by offering new opportunities for business development, new ways of promoting and selling products, resulting in the creation of new value. Entrepreneurs, of all sizes, are now using the internet to do business and also to reach new markets.

E-entrepreneurs benefit from more opportunities on the market but also have to face higher challenges because they are in different virtual locations, have different customers, different suppliers, but also other rival companies.

Through this paper, we aimed at identifying the differences between the European Union countries as regards the use of e-business, especially internet access and the existence of a website. For the purpose of this research, we grouped the countries by their stage of economic development. We also have analyzed the data in relative values and therefore we have considered as criteria of a significant change the value of $1 \%$ of the enterprises, because this value can, for some countries, express hundreds of thousands of enterprises.

Our results confirm the hypotheses and emphasize the fact that in more developed countries the use of information and communication technologies is more advanced compared to developing countries. According to our findings, businesses from EU countries definitely increased their average levels of ICT use in the period considered for analysis. Therefore, internet access is higher for entrepreneurs from innovation-driven economies, in some countries even reaching $100 \%$. For the transition economies, the share of enterprises that have access to the internet is still below the European Union average. Moreover, surprisingly, in some developing countries was even registered a reduction of access to the internet for the enterprises, in 2018 compared to 2010. As regards the existence of a website, although the evolution is positive starting with 2010 for all EU countries, in the countries in transition the share of the enterprises who own the website is still below the EU average.

We also observed significant differences when analyzing enterprises by size class. The general conclusion of these results was that as businesses are smaller in size, they register both low internet access or do not own a website. But when we look at large businesses, the percentage of those using e-business technologies is above the EU average. Also, in this part of the analysis, there were observed significant differences between the two groups of analyzed countries, pointing out that the stage of economic development of a country is an aiding factor for the use of e-business by the enterprises.

Moreover, we found that there are a lot of benefits of ICTs use for businesses. They take advantage of the new production capabilities generated by the use of informational technology. Businesses are trying to create new products to compete with the other businesses and for this purpose, they are implementing and using more and more the information technologies. To conclude, we can affirm that businesses from EU countries use ICTs in an active way, try to create new products, and make their productions convenient for their customers' needs.

\section{Acknowledgements}

This work was supported by a grant of the "Alexandru Ioan Cuza" University of Iasi, within the Research Grants program, Grant UAIC, code GI-UAIC-2017-02.

\section{Disclosure statement}

We, the authors, do not have any competing financial, professional, or personal interests from other parties. 


\section{References}

Ajmal, F., Yasin, N. M., \& Norman, A. A. (2017). Critical success factors influencing e-commerce adoption in SMEs: A review and model. International Journal of Advanced and Applied Sciences, 4(7), 159-172. https://doi.org/10.21833/ijaas.2017.07.023

Amankwah-Amoah, J., Osabutey, E., \& Egbetokun, A. (2018). Contemporary challenges and opportunities of doing business in Africa: The emerging roles and effects of technologies, In press. Technological Forecasting \& Social Change, 131(C), 171174. https://doi.org/10.1016/j.techfore.2018.01.003

Amit, R., \& Zott, C. (2001). Value creation in e-business. Strategic Management Journal, 22(6-7), 493-520. https://doi.org/10.1002/smj.187

Asghari, R., \& Gedeon, S. (2010). Significance and impact of Internet on the entrepreneurial process: E-entrepreneurship and completely digital entrepreneurship. In European Conference on Innovation and Entrepreneurship. Academic Conferences International Limited.

Asongu, S., \& Nwachukwu, J. (2018). Openness, ICT and entrepreneurship in sub-Saharan Africa. Information Technology \& People, 31(1), 278-303. https://doi.org/10.1108/ITP-02-2017-0033

Awazu, Y., Baloh, P., Desouza, K. C., Wecht, C. H., Kim, J., \& Jha, S. (2009). Information-communication technologies open up innovation. Research-Technology Management, 52(1), 51-58. https://doi.org/10.1080/08956308.2009.11657548

Bandera, C., Collins, R., \& Passerini, K. (2018). Risky business: Experiential learning, information and communications technology, and risk-taking attitudes in entrepreneurship education. The International Journal of Management Education, 16, 224-238. https://doi.org/10.1016/j.ijme.2018.02.006

Barnett, W., Hu, M., \& Wang, X. (2019). Does the utilization of information communication technology promote entrepreneurship: Evidence from rural China. Technological Forecasting and Social Change, 141, 12-21. https://doi.org/10.1016/j.techfore.2019.01.007

Carayannis, E. G., \& von Zedwitz, M. (2005). Architecting gloCal (global-local), real-virtual incubator networks (G-RVINs) as catalysts and accelerators of entrepreneurship in transitioning and developing economies: lessons learned and best practices from current development and business incubation practices. Technovation, 25(2), 95-110. https://doi.org/10.1016/S01664972(03)00072-5

Chae, H. C., Koh, C. E., \& Prybutok, V. R. (2014). Information technology capability and firm performance: contradictory findings and their possible causes. MIS Quarterly, 38(1), 305-314. https://doi.org/10.25300/MISQ/2014/38.1.14

Chivasa, S., \& Hurasha, C. (2016). Small and Medium Enterprises'(SMEs) Adoption and Usage of E-commerce: A probit modeling. International Journal of Economics, Commerce and Management, 4(3), 218-226.

Cuevas-Vargas, H., Estrada, S., \& Larios-Gómez, E. (2016). The effects of ICTs as innovation facilitators for a greater business performance. Evidence from Mexico. Procedia Computer Science, 91, 47-56. https://doi.org/10.1016/j.procs.2016.07.040

Cujia Berrio, S. E., Redondo, R., \& Hernández, H. (2018). Impact of ICT in the Generation of New Services Companies. Contemporary Engineering Sciences, 11(52), 2591-2599. https://doi.org/10.12988/ces.2018.86272

Daniel, E. M., \& Grimshaw, D. J. (2002). An exploratory comparison of electronic commerce adoption in large and small enterprises. Journal of Information Technology, 17(3), 133-147. https://doi.org/10.1080/0268396022000018409

Dutta, S., \& Evrard, P. (1999) Information technology and organisation within European small enterprises. European Management Journal, 17(30), 239-51. https://doi.org/10.1016/S0263-2373(99)00003-1

Eranga, W., Kennedy, G., \& Dushyanta, K. (2015). Impact of ICT usage on entrepreneurs' innovations \& business performance: A Review of Literature. In Proceedings of $12^{\text {th }}$ International Conference on Business Management (pp. 1-27). Retrieved from https://ssrn.com/link/12th-ICBM-2015.html

European Commission. (2018). Eurostat. Retrieved from https://ec.europa.eu/eurostat

Finkle, T. A., Krovi, R., Kahai, P. S., Dunning, K., \& Vijayaraman, B. S. (2000). Impact of E-commerce on entrepreneurs and small businesses: opportunities, challenges, and strategies. The Entrepreneurial Executive, 5, 65-84.

GEM. (2018). Global report 2017/2018. Wellesley, MA: Babson College. Retrieved from https://www.gemconsortium.org/report

Guillén, M. F., \& Suárez, S. L. (2001). Developing the Internet: entrepreneurship and public policy in Ireland, Singapore, Argentina, and Spain. Telecommunications Policy, 25(5), 349-371. https://doi.org/10.1016/S0308-5961(01)00009-X

Hanoteau, J., \& Rosa, J. (2019). Information technologies and entrepreneurship. Managerial and Decision Economics, 40(2), 200212. https://doi.org/10.1002/mde.2996

Hargittai, E. (1999). Weaving the western web: Explaining differences in Internet connectivity among OECD countries. Telecommunications Policy, 23(10-11), 701-718. https://doi.org/10.1016/S0308-5961(99)00050-6

Hempell, T., van Leeuwen, G., \& van der Wiel, H. (2004). ICT, innovation and business performance in services: evidence for Germany and the Netherlands (ZEW Discussion Paper No. 04-06, pp. 131-152). Mannheim, The Economic Impact of ICT, Measurement, Evidence and Implications, Paris. https://doi.org/10.2139/ssrn.545183

Ifinedo, P. (2011). Internet/e-business technologies acceptance in Canada's SMEs: an exploratory investigation. Internet Research, 21(3), 255-281. https://doi.org/10.1108/10662241111139309

Jelonek, D. (2015). The role of open innovations in the development of e-entrepreneurship. Procedia Computer Science, 65, 10131022. https://doi.org/10.1016/j.procs.2015.09.058

Johannessen, J. A. (1994). Information technology and innovation: identifying critical innovation factors. Information Management \& Computer Security, 2(2), 4-9. https://doi.org/10.1108/09685229410059532 
Karadal, H., \& Saygin, M. (2011). The effect of information technology on innovation abilities: A research on SMEs. In International Conference on Eurasian Economies (pp. 396-399). Bishkek - Kyrgyzstan: Manas University Press.

Kaynak, E., Tatoglu, E., \& Kula, V. (2005). An analysis of the factors affecting the adoption of electronic commerce by SMEs: Evidence from an emerging market. International Marketing Review, 22(6), 623-640. https://doi.org/10.1108/02651330510630258

Kohli, R., \& Devaraj, S. (2003). Measuring information technology payoff: a meta-analysis of structural variables in firm level empirical research. Information Systems Research, 14(2), 127-145. https://doi.org/10.1287/isre.14.2.127.16019

Levenburg, N. M., Schwarz, T. V., \& Motwani, J. (2005). Understanding adoption of internet technologies among SMEs. Journal of Small Business Strategy, 16(1), 51-70.

MacGregor, R. C., \& Kartiwi, M. (2010). Perception of barriers to e-commerce adoption in SMEs in a developed and developing country: a comparison between Australia and Indonesia. Journal of Electronic Commerce in Organizations (JECO), 8(1), 6182. https://doi.org/10.4018/jeco.2010103004

Manuel, E. (2006). E-entrepreneurship (MPRA Paper No. 2237). University Library of Munich, Germany. https://doi.org/10.2139/ssrn.940647

Markides, C. C. \& Anderson, J. (2006). Creativity is not enough: ICT - enabled strategic innovation. European Journal of Innovation, 9, 129-148. https://doi.org/10.1108/14601060610663532

Matlay, H. (2004). E-entrepreneurship and small e-business development: towards a comparative research agenda. Journal of Small Business and Enterprise Development, 11(3), 408-414. https://doi.org/10.1108/14626000410551663

Melville, N., Kraemer, K., \& Gurbaxani, V. (2004). Review: information technology and organization performance: an integrative model of IT business value. MIS Quarterly, 28(1), 283-322. https://doi.org/10.2307/25148636

Nguyen, T. H. (2009). Information technology adoption in SMEs: an integrated Framework. International Journal of Entrereneurial Behavior \& Research, 15(2), 162-186. https://doi.org/10.1108/13552550910944566

Oxley, J. E., \& Yeung, B. (2001). E-commerce readiness: Institutional environment and international competitiveness. Journal of International Business Studies, 32(4), 705-723. https://doi.org/10.1057/palgrave.jibs.8490991

Pavlou, P. A., \& Ei Sawy, O. A. (2006). From IT leveraging competence to competitive advantage in turbulent environments: the case of new product development information. Information Systems Research, 17(3), 198-227. https://doi.org/10.1287/isre.1060.0094

Powell, T. C., \& Micallef, A. D. (1997). Information technology as competitive advantage: the role of human, business and technology resources. Strategic Management Journal, 18, 375-405. https://doi.org/10.1002/(SICI)1097-0266(199705)18:5<375::AID-SMJ876>3.0.CO;2-7

Roman, A., \& Rusu, V. D. (2011). Constraints on bank lending to SMEs from Romania and supportive measures. EuroEconomica, 30(5), 21-38.

Schwab, K. (2018). The global competitiveness report 2018. Insight report. World Economic Forum.

Schwab, K., \& Sala-i-Martin, X. (2016). The global competitiveness report 2016-2017. Insight report. World Economic Forum.

Schwab, K., \& Sala-i-Martin, X. (2017). The global competitiveness report 2017-2018. Insight report. World Economic Forum.

Sin Tan, K., Choy Chong, S., Lin, B., \& Cyril Eze, U. (2009). Internet-based ICT adoption: evidence from Malaysian SMEs. Industrial Management \& Data Systems, 109(2), 224-244. https://doi.org/10.1108/02635570910930118

Solaymani, S., Sohaili, K., \& Yazdinejad, E. A. (2012). Adoption and use of e-commerce in SMEs. Electronic Commerce Research, 12(3), 249-263. https://doi.org/10.1007/s10660-012-9096-6

Spiezia, V. (2011). Are ICT users more innovative? An analysis of ICT-enabled innovation in OECD firms. OECD Journal: Economic Studies, 2011(1), 1-21. https://doi.org/10.1787/eco_studies-v2010-1-en

Stansfield, M., \& Grant, K. (2003). An investigation into issues influencing the use of the internet and electronic commerce among small-medium sized enterprises. Journal of Electronic Commerce Research, 4(1), 15-33.

Szczepański, M. (2015). A connected digital single market. State of play and the way forward. Retrieved from http://www.europarl.europa.eu/RegData/etudes/BRIE/2015/545734/EPRS_BRI\%282015\%29545734_REV1_EN.pdf

Taylor, M., \& Murphy, A. (2004). SMEs and e-business. Journal of Small Business and Enterprise Development, 11(3), $280-289$. https://doi.org/10.1108/14626000410551546

Urbinati, A., Chiaroni, D., Chiesa, V., \& Frattini, F. (2018). The role of digital technologies in open innovation processes: an exploratory multiple case study analysis. R\&D Management (Special issue Paper). https://doi.org/10.1111/radm.12313

Van Deursen, A., \& van Dijk, J. (2014). Loss of labor time due to malfunctioning ICTs and ICT skill insufficiencies. International Journal of Manpower, 35(5), 703-719. https://doi.org/10.1108/IJM-07-2012-0102

Waesche, N. M. (2003). Internet entrepreneurship in Europe: venture failure and the timing of telecommunications reform. Cheltenham, UK: Edward Elgar Pub. https://doi.org/10.4337/9781781951330

World Bank. (2018). World development indicators. Retrieved from https://data.worldbank.org/data-catalog/worlddevelopmentindicators

Zhao, F. (2005). Entrepreneurship and innovation in e-business: an integrative perspective. The International Journal of Entrepreneurship and Innovation, 6(1), 53-60. https://doi.org/10.5367/0000000053026428

Zoroja, J. (2016). Impact of ICTs on innovation activities: indication for selected European countries. Naše Gospodarstvo/Our Economy, 62(3), 39-51. https://doi.org/10.1515/ngoe-2016-0017 